\title{
Mortality of Little Brown Bats, Myotis lucifugus, in a Rodent Trap in the Boreal Forest
}

\author{
Thomas S. Jung ${ }^{1}$ and Brian G. SlOugh ${ }^{2}$ \\ ${ }^{1}$ Yukon Department of Environment, Box 2703, Whitehorse, Yukon Y1A 2C6 Canada; e-mail: thomas.jung@gov.yk.ca \\ 235 Chronkite Road, Whitehorse, Yukon Y1A 5S9 Canada; e-mail: slough@ northwestel.net
}

Jung, Thomas S., and Brian G. Slough. 2005. Mortality of Little Brown Bats, Myotis lucifugus, in a rodent trap in the boreal forest. Canadian Field-Naturalist 119(4): 589-590.

Accidental mortality of bats is not often observed or reported in the literature. It may, however, have an impact on population size and structure. We report an observation of 53 Little Brown Bats (Myotis lucifugus) being trapped and drowned in a homemade rodent trap at an abandoned cabin in southern Yukon. Traps of this design may be commonly used in the boreal forest. We recommend not using such traps in cabins that are used by colonies of bats.

Key Words: Little Brown Bat, Myotis lucifugus, mortality, trap, Yukon.

Accidental mortality of bats is not often observed or reported in the literature (Johnson 1933; Manville 1963). Among the causes of mortality indirectly caused by humans (i.e. unintentional, or accidental mortality), several have been noted for bats. For example, poisoning (e.g., Kunz et al. 1977; Clark et al. 1978; Pybus et al. 1986), human disturbance at roosting colonies or hibernacula (e.g. Tuttle 1979; Thomas 1995; Johnson et al. 1998), entanglement in exotic burdock (Arctium spp.; e.g., Lyon 1925; Hendricks et al. 2003), and collisions with wind turbines (e.g., Johnson et al. 2003), have been noted as observed or potential causes of accidental mortality. Curiously, few other sources of accidental mortality have been reported for bats. Yet, in some cases, accidental mortality may have an effect on colony size or structure that is equal to or greater than natural mortality (i.e., predation, disease, starvation, etc). Here, we report an observation of mortality of Little Brown Bats (Myotis lucifugus) in a homemade trap that is commonly used in buildings in the Canadian boreal forest to capture mice (Peromyscus spp.).

On 8 September 2004 we found 53 dead and desiccated Little Brown Bats in a rodent trap in a cabin near Squanga Lake, Yukon $\left(60.5^{\circ} \mathrm{N}, 133.5^{\circ} \mathrm{W}\right)$. We were unable to reliably ascertain the age or sex of individuals. The specimens have been retained by the Yukon Department of Environment. No rodents were found in the trap.

The cabin was abandoned and housed a maternity colony of Little Brown Bats since at least 2000 (Slough $2001 *)$. Colony size before this incident of mortality was estimated at about 85-100 adults on 29 June 2004 (Jung and Slough, unpublished data), based on emergence counts and captures with a harp trap (Tuttle 1974). The rodent trap was prominently placed in an empty room that was regularly used for flight activity by bats after arousal and before they exited the cabin.

The rodent trap was homemade and of a design that is commonly used in the Canadian boreal forest where remote cabins are left unoccupied for several months at a time, particularly by seasonal trappers, hunters, and fishers (H. Jessup, personal communication). These traps are regularly made of 19 litre ( 5 gallon) buckets

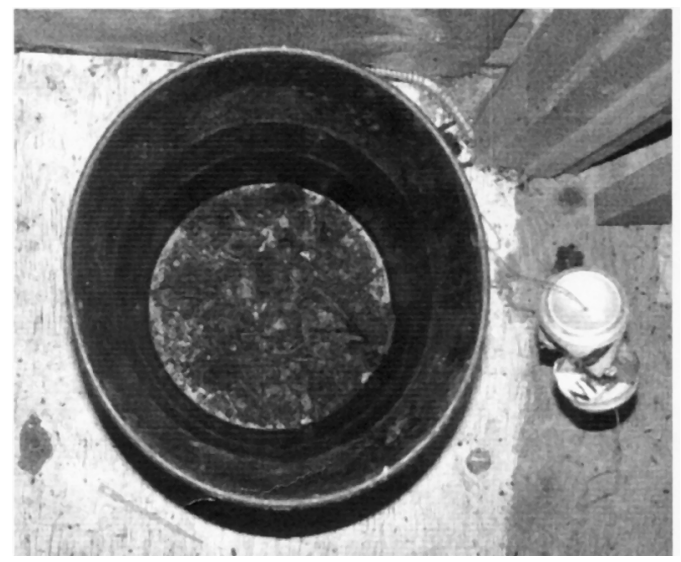

FIGURE 1. Homemade "bucket" trap with 53 mummified little brown bats (Myotis lucifugus). Note the wire and rotating bait can that was used on the trap, but removed for this photograph.

(31.4 $\mathrm{cm}$ in diameter by $38.7 \mathrm{~cm}$ tall) that are halffilled with water. A wire or rope is strung across the top opening of the bucket and a beverage can (approximately $335 \mathrm{ml}$ ) is placed along the middle of the wire or rope. Rodents walk along the rope to reach bait that is placed in the can and fall into the bucket and drown. The trap is designed to catch multiple rodents, primarly Peromyscus.

We suspect that Little Brown Bats attempted to drink from the bucket upon arousal from diurnal roosting and became trapped and drowned. Some bats, including Little Brown Bats, routinely drink after diurnal roosting bouts and before foraging. Alternatively, some bats may not have attempted to enter the bucket to drink, but had tripped on the wire while flying low above the bucket and fell into the bucket and drowned. Trip-lines over water have been used as a live-capture technique for bats. Regardless, we believe that the water in the bucket was likely the attractant that led to bats 
becoming trapped and drowning in the bucket. It is plausible that the distress calls of one bat trapped in the bucket attracted conspecifics, which then shared the same fate (Barclay 1982; B. Fenton, personal communication). Hendricks et al. (2003) suggested a similar scenario for multiple bats becoming entangled in burdock.

Because Little Brown Bats tend to have long life spans and low annual productivity (Fenton and Barclay 1980; van Zyll de Jong 1985), it is reasonable to suggest that accidental mortalities may, in some cases, have a substantial effect on colony size or structure. We suspect that this incident of accidental mortality may have substantially reduced the size of the Squanga Lake colony. We do not know how common it is to capture bats in this type of rodent trap, but suspect that it may happen somewhat regularly, with unknown effects on Little Brown Bat populations in remote boreal forest ecosystems. We strongly recommend that rodent traps of this or a similar design not be used in buildings when they are occupied by colonies of bats.

\section{Acknowledgments}

We thank B. Bennett for helping us solve the mystery of "how the bats got in the bucket". Financial support was provided by the Yukon Department of Environment and a Northern Research Endowment Grant from the Northern Research Institute, Yukon College.

Documents Cited (marked $*$ in the text)

Slough, B. G. 2001. A survey of the bat fauna of the Yukon Territory: 2000 field studies. Unpublished report. Northern Research Institute, Yukon College, Whitehorse, Yukon. 18 pages.

\section{Literature Cited}

Barclay, R. M. R. 1982. Interindividual use of echolocation calls: eavesdropping by bats. Behavoural Ecology and Sociobiology 10: 271-275.
Clark, D. R., R. K. La Val, and D. M. Swineford. 1978. Dieldren-induced mortality in an endangered species, the gray bat (Myotis grisescens). Science 199:1357-1359.

Fenton, M. B., and R. M. R. Barclay. 1980. Myotis lucifugus. Mammalian Species 142: 1-8.

Hendricks, P., J. Carlson, and C. Currier. 2003. Fatal entanglement of western long-eared myotis in burdock. Northwestern Naturalist 84: 44-45.

Johnson, P. B. 1933. Accidents to bats. Journal of Mammalogy 14: 156-157.

Johnson, G. D., W. P. Erickson, M. D. Strickland, M. F. Shepherd, D. A. Shepherd, and S. A. Sarappo. 2003. Mortality of bats at a large-scale wind power development at Buffalo Ridge, Minnesota. American Midland Naturalist 150: 332-342.

Johnson, S. A., V. Brack Jr., and R. E. Rolley. 1998. Overwinter weight loss of Indiana bats (Myotis sodalis) from hibernacula subject to human visitation. American Midland Naturalist 139: 255-261.

Kunz, T. H., E. L. P. Anthony, and W. T. Rumage. 1977. Mortality of little brown bats following multiple pesticide applications. Journal of Wildlife Management 41: 476-483.

Lyon, M. W. 1925. Bats caught by burdocks. Journal of Mammalogy 6: 280 .

Manville, R. H. 1963. Accidental mortality in bats. Mammalia. 27: 361-366

Pybus, M. J., D. P. Hobson, and D. K. Onderka. 1986. Mass mortality of bats due to probable blue-green algal toxicity. Journal of Wildlife Diseases 22: 449-450.

Thomas, D. W. 1995. Hibernating bats are sensitive to nontactile human disturbance. Journal of Mammalogy 76: 940-946.

Tuttle, M. D. 1974. An improved trap for bats. Journal of Mammalogy 55: 475-477.

Tuttle, M. D. 1979. Status, causes of decline and management of endangered gray bats. Journal of Wildlife Management 43: $1-7$.

van Zyll de Jong, C. G. 1985. Handbook of Canadian mammals. Vol. 2: Bats. National Museum of Natural Sciences, Ottawa, Ontario. 212 pages.

Received 18 March 2005

Accepted 26 October 2005 